\title{
Effect of Chemotherapy and Immunotherapy on Tumor-Specific Immunity in Melanoma
}

\author{
Malcolm S. Mitchell, Margalit Birnbaum Mokyr, and Jean Merrill Davis \\ From the Departments of Medicine and Pharmacology, Yale University School of Medicine and the \\ Yale-New Haven Hospital, New Haven, Connecticut 06510
}

A BSTRACT The effects of chemotherapy, with nitrosoureas or dimethyl-triazeno-imidazole-carboxamide (DTIC), or immunotherapy with Bacillus Calmette-Guérin (BCG), on cell-mediated immunity (CMI), and serum blocking factor (BF) to melanoma cells were studied in 23 patients. Studies were performed with autologous or allogenic melanoma target cells obtained from recent biopsy, in $16 \mathrm{~mm}$ diameter plastic wells. Assays for lymphocyte-mediated cytotoxicity and BF were performed at weekly intervals over the course of 3-4 mo, with some studies extending beyond $3 \mathrm{yr}$. The specificity of cytotoxicity was good with these methods. Nine patients given nitrosoureas, predominantly methyl-chloroethyl-cyclohexylnitrosourea, showed a transient decline in CMI from 42.2 to $14 \% 3 \mathrm{wk}$ after administration of a single dose of the agent, with a rapid recovery within 1 wk. 10 patients given 5-day courses of DTIC at 3-wk intervals showed no decline in CMI after two courses, and 7 of the 10 had no decline even after three courses. Three of the four patients who achieved a remission lost BF previously present; $B F$ reappeared in both patients studied during a subsequent relapse. BCG intradermally or intralesionally elevated CMI within 2 mo after initiation of therapy, but despite continuation of the injections CMI returned to base line in all but two of the nine patients studied. These results indicate that chemotherapy for melanoma with nitrosoureas or DTIC at these schedules is not profoundly immunosuppressive towards tumor-specific immunity, as measured by our procedures. Putative

Dr. Mitchell is the recipient of a Research Career Development Award, no. 5K0470982, National Cancer Institute, National Institutes of Health.

Address reprint requests to Dr. Malcolm S. Mitchell, Yale University School of Medicine, New Haven, Conn. 06510.

Received for publication 6 May 1976 and in revised form 19 January 1977. immunotherapy with BCG at these schedules was likewise only transiently stimulatory.

\section{INTRODUCTION}

It has been appreciated since the late 1950's that many of the agents commonly used in the chemotherapy of cancer are immunosuppressive (1). This has led to an extension of their use, such as in the therapy of allograft rejection and autoimmune disorders. However, during the same period of time, other investigations have emphasized the importance of the immune response in the rejection of tumors in rodents, and its probable importance in man $(2,3)$. Oncologists treating patients with cancer have been justifiably concerned about the possible immunosuppressive effects of chemotherapeutic agents, since suppression of tumor-specific immunity might prevent optimal tumoricidal effects. One approach to analyzing this problem has been to test patients with exogenous antigens during the course of chemotherapy, to judge whether their immunological capacity was impaired. These studies have generally demonstrated immunosuppression by several different agents (4-6), although at least one agent, dimethyl-triazeno-imidazolecarboxamide (DTIC), ${ }^{1}$ was much less suppressive than most (7). Yet it has remained possible that the response towards tumor-associated antigens (tumorspecific immunity) might be very different from that towards the exogenous microbial and chemical antigens used to test general immunological capacity. We therefore decided to study the influence of chemotherapy upon immunity to antigenic tumor cells, with melanoma in man as a model system.

\footnotetext{
${ }^{1}$ Abbreviations used in this paper: BCG, Bacillus CalmetteGuérin; BF, blocking factor; CCNU, cyclohexyl-chloroethylnitrosourea; methyl-CCNU, methyl-chloroethyl-cyclohexylnitrosourea; CMI, cell-mediated immunity; DTIC, dimethyltriazeno-imidazole-carboxamide.
} 
The immunological response to human melanoma has been well-studied by several investigators (8-13), and some of the earliest attempts to utilize active immunotherapy as a mode of treatment in man were in this disease (14). Indeed, the regression of intradermal nodules in one-half the patients who received Bacillus Calmette-Guérin (BCG) intralesionally (14), as well as the spontaneous regressions occasionally observed in the untreated disease, have strongly suggested that melanoma epitomizes those tumors that potentially might be rejected by an immunocompetent host. Lymphocyte-mediated immunity (cell-mediated immunity, [CMI]) is usually found in patients with melanoma, and is generally higher in patients with local or recently resected disease (10). Serum blocking factor (BF) present in many patients with disseminated disease decreases or abrogates the effectiveness of cytotoxic lymphocytes in vitro, and significantly reduces the CMI obtainable with even high ratios of lymphocytes to target tumor cells (8). The presence or absence of $\mathrm{BF}$ has been said to correlate with the status of the disease $(9,11)$, but whether $\mathrm{BF}$ simply reflects or somehow causes metastasis is an important unresolved issue.

We have studied patients treated with standard schedules of DTIC or one of the nitrosourea derivatives (e.g., methyl-chloroethyl-cyclohexyl-nitrosourea, [methyl-CCNU]) with serial assays for CMI and BF to quantitate variations in their response to melanoma. In addition, we have studied patients undergoing active immunotherapy with BCG to determine any systemic changes in immunological responsiveness to melanoma antigens caused by this form of treatment. Our results indicate that chemotherapy with these agents was minimally immunosuppressive against tumor-specific immunity but that putative immunotherapy, too, only transiently altered CMI.

\section{METHODS}

Tumor cells. Individual cultures of melanoma cells were obtained by excisional biopsy of intradermal or subcutaneous nodules from each of four patients, J. McH., E. H., J. P., and R. P. The nodules were minced sterilely and teased with curved scissors or scalpel blades and were filtered through sterile cotton gauze to remove large clumps of cells. Dispersed melanoma cells were washed and cultivated in Waymouth's medium with 20 or $30 \%$ newborn or fetal calf serum in Corning No. 25100 disposable polystyrene flasks (Corning Glass Works, Science Products Div., Corning, N. Y.) in a moist atmosphere of $5 \% \mathrm{CO}_{2}$ and $95 \%$ air. Cells from the initial biopsy or from an early passage of the tumor were frozen in Waymouth's medium with $10 \%$ dimethylsulfoxide, in $1-\mathrm{ml}$ portions at $-70^{\circ} \mathrm{C}$. New cultures were started to replace cells continuously cultivated for 3-4 mon to avoid any problems associated with long-term cultures. Tests were performed for mycoplasma infection periodically, but no contamination was found. Cultures used for assay were also free of contamination by fibroblasts. Melanoma cells were identified by their typical appearance, including nonuniformity of nuclear size, loss of polarity, and content of melanin pigment, as seen by phase-contrast microscopy. Chromosomal analysis was not performed. Normal fibroblasts (controls) were grown as a monolayer from normal skin or kidney biopsy material.

Cytotoxicity assay. Our modification of the procedure of Hellstrom and Hellstrom (15), after Takasugi and Klein (16), was used for the measurement of CMI. Linbro sterile plastic trays with 24 wells, each $16 \mathrm{~mm}$ in diameter (Linbro Chemical Co., New Haven, Conn.) were seeded with 250 autologous or allogenic tumor cells in Waymouth's medium, which were allowed to settle overnight at $37^{\circ} \mathrm{C}$ in $5 \%$ $\mathrm{CO}_{2}-95 \%$ air. Peripheral blood lymphocytes were obtained from a Ficoll-Hypaque gradient centrifugation of $20 \mathrm{ml}$ of heparinized human blood (17) and were further purified by removal of glass-adherent monocytes for $45 \mathrm{~min}$ at $37^{\circ}$ in a l-liter medicine bottle. 50,000 $\left(5 \times 10^{4}\right)$ lymphocytes were added to each well in triplicate or quadruplicate, making the initial ratio of effector to target cells 200:1, a low ratio for this type of assay (10). This was chosen after preliminary experiments indicated the cytotoxic effectiveness of this ratio, with a high degree of specificity. One group of wells was incubated with serum from the same patient for 30-45 min before lymphocytes were added, to test for $\mathrm{BF}$ activity. After $48 \mathrm{~h}$ of incubation in $5 \% \mathrm{CO}_{2}-95 \%$ air at $37^{\circ} \mathrm{C}$, remaining morphologically intact tumor cells were counted by inverted phase-contrast microscopy. Comparison of the number of melanoma cells in the test wells with wells containing no lymphocytes or lymphocytes from normal individuals lacking cytotoxicity against melanoma cells (see Results) was expressed as percentage lysis, or:

$$
100 \times \frac{\begin{array}{c}
\text { no. of cells in control well } \\
\text { no. of cells in experimental well }
\end{array}}{\text { no. of cells in control well }}
$$

Control wells usually contained 100-180 tumor cells after $48 \mathrm{~h}$ (mean, approximately 160 ), the readings varying by no more than $\pm 15 \%$ (SD) even among different observers. Replicate values for experimental wells also varied by $\pm 15 \%$ (SD) from the mean. Usually this represented a difference of 5-10 cells per well, compared with a mean of approximately 70 cells in wells from patients before treatment. For this reason we have operationally considered an absolute CMI of $\geqslant 15 \%$ with test lymphocytes to be significant compared with control wells without lymphocytes. Formal statistical comparisons among groups were made with Student's $t$ test.

If in the presence of serum there was more than a $20 \%$ absolute decrease in the percentage of lymphocyte-mediated lysis, significant blocking activity was considered to be present. Our use of this net CMI in the presence of serum is a slightly different expression of $\mathrm{BF}$ from that presented by the Hellstroms, who have referred to percentage of blocking, i.e., the percentage of CMI abrogated by serum. Thus, if CMI decreased from 30 to $10 \%$, we would cite a net CMI of $10 \%$, and $20 \%$ blocking activity, whereas this would constitute a $66.6 \%$ blocking (20/30) in the Hellstroms' terminology. Our main reason for emphasizing absolute values was to avoid equating a fall from $80 \%$ lysis to $40 \%$ with one from 20 to $10 \%$, which might have far different in vivo consequences. Helper activity in serum was defined as that causing increased CMI compared with lymphocytes alone.

Patients and their therapy. A total of 23 patients were studied. Of these, seven had recently undergone surgical resection of their primary tumor site and usually of regional lymph nodes as treatment for Stage II melanoma. The other 16 patients had metastatic melanoma involving one or 
more viscera, or the subcutaneous or intradermal regions. Several of the patients were followed from a time at which they had no evidence of disease through the development of metastases and treatment with one or more chemotherapeutic agents.

Immunoprophylactic therapy of patients with Stage II melanoma (involving regional lymph nodes) after surgery consisted of the intradermal inoculation of BCG into uninvolved skin of the deltoid region or back. This route was chosen because the number of organisms inoculated could be precisely quantitated, permitting correlations of dose and response. BCG was inoculated intralesionally into four patients with intradermal melanoma. Chemotherapy consisted of DTIC or one of the nitrosoureas, either cyclohexyl-chloroethyl-nitrosourea (CCNU) or methyl-CCNU. DTIC was given as a 5 -day course of $150-250 \mathrm{mg} / \mathrm{m}^{2} /$ day i.v. every 3 or 4 wk. The nitrosoureas were given as a single oral dose every $6 \mathrm{wk}, 130 \mathrm{mg} / \mathrm{m}^{2}$ for CCNU and $200-250$ $\mathrm{mg} / \mathrm{m}^{2}$ for methyl-CCNU. Two patients received vincristine $1.4 \mathrm{mg} / \mathrm{m}^{2}$ i.v. with CCNU early in the study.

Details of the composition of the group and the results in individual patients are given in the Appendix.

\section{RESULTS}

Effects of nitrosoureas on CMI. Nine patients were given nitrosourea derivatives, predominantly methylCCNU, $200-250 \mathrm{mg} / \mathrm{m}^{2}$ as a single oral dose. The mean CMI for this group was $42.2 \% \pm 6.2$ (SE) (Fig. 1) before treatment. $3 \mathrm{wk}$ after the nitrosourea, the mean CMI reached a nadir of $14.4 \% \pm 7.0$ (SE); eight of nine patients showed this depression of immunity. Within 1 wk after this nadir, however, the CMI rebounded to pretreatment levels, and remained steady during the 4 subsequent wk of study. An overshoot (i.e., rebound above pretreatment level) was noted in only two of nine patients (M. L. P. and K. P.). Four patients (J. P., J. McH., P. D., and R. P.) received more than one course of a nitrosourea. Although their CMI showed a lesser depression on subsequent courses than on the first, no firm conclusions can be

\section{MELANOMA: NITROSOUREAS (9 pts)}

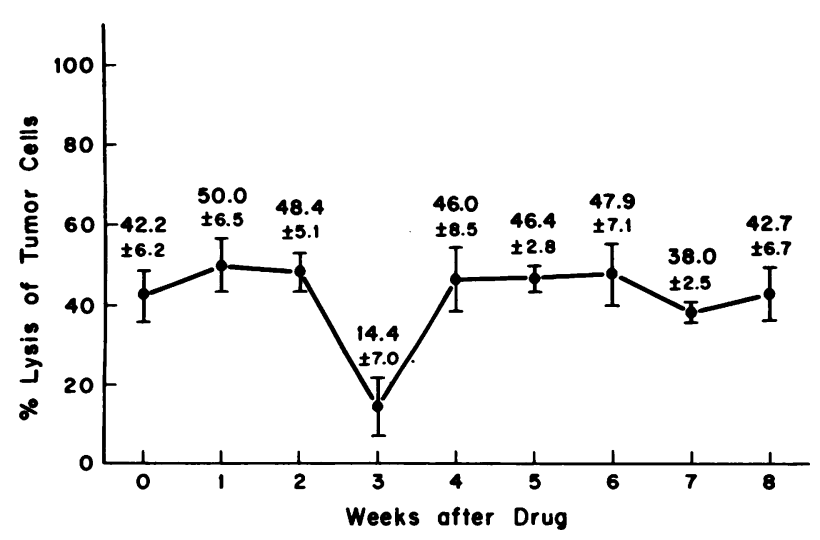

FIGURE 1 Effect of nitrosoureas on lymphocyte-mediated lysis of melanoma cells. Mean $\pm \mathrm{SE}$ given for each point.

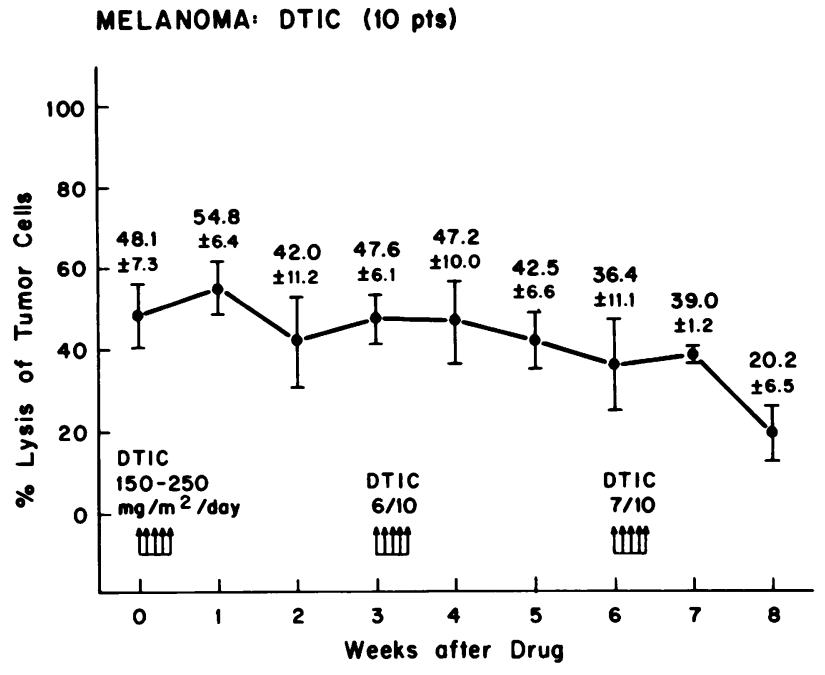

FIGURE 2 Effect of DTIC on lymphocyte-mediated lysis of melanoma cells. Mean $\pm \mathrm{SE}$ given for each point.

drawn on the possible development of resistance to suppressive effects of the drug.

The number of circulating lymphocytes in these patients, calculated from the total leukocyte count and differential, was not correlated with the level of CMI. A decline in the leukocyte count, principally the granulocytes, was found 4-6 wk after administration of nitrosoureas, 1-3 wk after the lowest level of CMI had been reached. Since only three of the nine patients achieved a (partial) remission, it is unlikely that a transient effect on the tumor, and thus a decreased antigenic stimulation of lymphocytes by the tumor, was responsible for the decrease in CMI. A sequestration or temporary inactivation of a subpopulation of circulating lymphocytes is possible, but has not yet been investigated further.

Effect of DTIC on CMI. 10 patients were treated with DTIC, usually at 3-wk intervals, at a dose of $150-250 \mathrm{mg} / \mathrm{m}^{2} /$ day intravenously for 5 days. Two of the patients received DTIC at 4-wk intervals and a third patient received a second course only at $6 \mathrm{wk}$ because of leukopenia. The pretreatment mean CMI in the group was $48.1 \% \pm 7.3$ (SE) and remained at essentially this level throughout the first 6 wk of therapy (Fig. 2). At $8 \mathrm{wk}, 2 \mathrm{wk}$ after the third course of therapy, there was a lower $(P<0.05)$ level of CMI than before treatment, with a mean of $20.2 \% \pm 6.51$. This was due mainly to a significant decrease noted in 3 of the 10 patients. The other seven patients had no decrease in CMI at any time during therapy. Mild to moderate leukopenia occurred 3-4 wk after a course of DTIC, but there was no correlation of lymphocytopenia with a decreased level of CMI in any patient.

Effect of a combination of DTIC and a nitrosourea on CMI. Two patients, W. C. and E. S., were treated 
TABLE I

Examples of Controls for Specificity

\begin{tabular}{|c|c|c|c|}
\hline Subject & Status & Target cells & CMI \\
\hline & & & $\%$ \\
\hline \multicolumn{4}{|c|}{ (A) Cancer patients } \\
\hline \multirow[t]{4}{*}{ E. S. } & Melanoma patient (Metas.)* & Allogenic (J. P.) & 58 \\
\hline & & Allogenic (R. P.) & 59 \\
\hline & & Osteosarcoma & 18 \\
\hline & & Fibroblasts & 15 \\
\hline \multirow[t]{4}{*}{ J. P. } & Melanoma patient (Metas.) & Allogenic (E. H.) & 60 \\
\hline & & Autologous & 78 \\
\hline & & Fibroblasts & 8 \\
\hline & & Neuroblastoma & 10 \\
\hline \multirow[t]{3}{*}{ B. $\mathbf{H}$. } & Melanoma patient & Allogenic & 69 \\
\hline & & Neuroblastoma & 18 \\
\hline & & Fibroblasts & 6 \\
\hline \multirow[t]{3}{*}{ P. R.t } & Melanoma patient & Allogenic & 47 \\
\hline & & Neuroblastoma & 20 \\
\hline & & Fibroblasts & 5 \\
\hline \multirow[t]{2}{*}{ L. F.t } & Melanoma patient (Metas.) & Allogenic & 44 \\
\hline & & Ovarian carcinoma & 4 \\
\hline \multirow[t]{2}{*}{ G. E.t } & Melanoma patient & Allogenic & 57 \\
\hline & & Ovarian carcinoma & 19 \\
\hline \multirow[t]{2}{*}{ A. M.t } & Melanoma patient & Allogenic & 59 \\
\hline & & Ovarian carcinoma & 21 \\
\hline O. R. & Ovarian carcinoma patient & Melanoma (E. H.) & 15 \\
\hline G. C. & Ovarian carcinoma patient & Melanoma (E. H.) & 13 \\
\hline R. H. & Epidermoid carcinoma patient & Melanoma (E. H.) & 9 \\
\hline P. N. & Epidermoid carcinoma patient & Melanoma (E. H.) & 3 \\
\hline \multicolumn{4}{|c|}{ (B) Normal subjects } \\
\hline M. M. & Physician & Allogenic (J. McH.) & 30 \\
\hline K. H. & Tissue culture technician & Allogenic (E. H.) & 35 \\
\hline R. B. & Chemistry technician & Allogenic (E. H.) & 16 \\
\hline B. $\mathbf{M}$. & AML, patient $\S$ & Allogenic (E. H.) & 18 \\
\hline A. $\mathbf{R}$. & College student & Allogenic (E. H.) & 10 \\
\hline L. T. & College student & Allogenic (E. H.) & 15 \\
\hline
\end{tabular}

* Metas., Patient had metastatic melanoma. Other melanoma patients were studied early during a course of immunotherapy.

I Patients with this notation were studied recently by the same techniques to further prove specificity and were not included in the investigations reported.

$\$$ AML, acute myelocytic leukemia.

with a combination of DTIC $100 \mathrm{mg} / \mathrm{m}^{2} / \mathrm{day} \times 5$ i.v. every $3 \mathrm{wk}$, and methyl-CCNU $100 \mathrm{mg} / \mathrm{m}^{2}$ per os every $6 \mathrm{wk}$. The response of their CMI resembled that seen after a nitrosourea alone, with a nadir at 3-4 wk and a prompt recovery thereafter.

Specificity of the CMI reaction. Reactivity against several allogenic melanomas was similar in an individual patient and was somewhat lower than with autologous cells. Minimal CMI reactivity $(<25 \%)$ against several primary cultures of human fibroblasts or dissimilar tumor cells (osteosarcoma, neuroblastoma, or ovarian carcinoma) was encountered with a patient's lymphocytes as effectors (Table I). This suggested that the patients were responding specifically to melanoma cells rather than simply to alloantigens or rapidly proliferating (tumor) cells. Similarly, patients with other types of tumor did not respond to melanoma cells. Whether putatively normal individuals also react to melanoma cells is a separate issue that we did not explore extensively, since it was not entirely germane to this study. Nevertheless, it should be noted that with short-term primary cultures of melanoma cells rather than cell lines, and with a relatively low ratio of effector:target cells (200:1), we did not usually find nonspecific cytolysis of tumor cells by lymphocytes from several normal donors. Four putatively normal individuals without contact with patients or tissue culture media had less than 20\% CMI to melanoma cells (Table I). Physicians, nurses, and laboratory technicians working with tissue culture (such as M. M. and K. H. in Table I) often had levels approximating that of patients, but these individuals cannot be strictly classified as normal together with the public at large. With the same ratio of effector to target cell and ABO typing a cell line (provided by Dr. M. Romsdahl, M.D. Anderson Hospital, Houston, Tex.) has yielded more frequent instances of "nonspecificity" with higher levels of CMI. ${ }^{2}$ These results are in agreement with those of DeVries et al. (12), who have specifically addressed themselves to this problem.

Effect of chemotherapy on BF. Three of the four patients (J. McH., J. P., R. P., and S. C.) who achieved a good partial remission after chemotherapy had BF before therapy. During remission BF was lost in each patient. Significantly, this loss of BF was noted in two patients during a remission induced by DTIC, an agent previously shown not to be immunosuppressive towards antibody synthesis (7). Both patients studied during a subsequent relapse regained $\mathrm{BF}$ concomitant with the onset of relapse. BF and relapse were present simultaneously and it was impossible to ascertain whether the reappearance of $\mathrm{BF}$ antedated relapse or vice versa. Although 16 patients had proved disseminated melanoma, only 4 of them had BF by our determination. Yet it was only these patients with dissemination who had BF.

Effect of BCG on CMI and BF. Five patients with recently resected deeply invasive primary melanoma and/or a regional node metastasis were treated with BCG immunoprophylaxis. A sixth patient with extensive cryosurgery of an intranasal melanoma was also treated. BCG of the Tice strain (Research Foundation, Chicago, Ill.) was administered intradermally at doses

${ }^{2}$ Mitchell, M. S. Unpublished data. 
MELANOMA: BCG (7 pts)

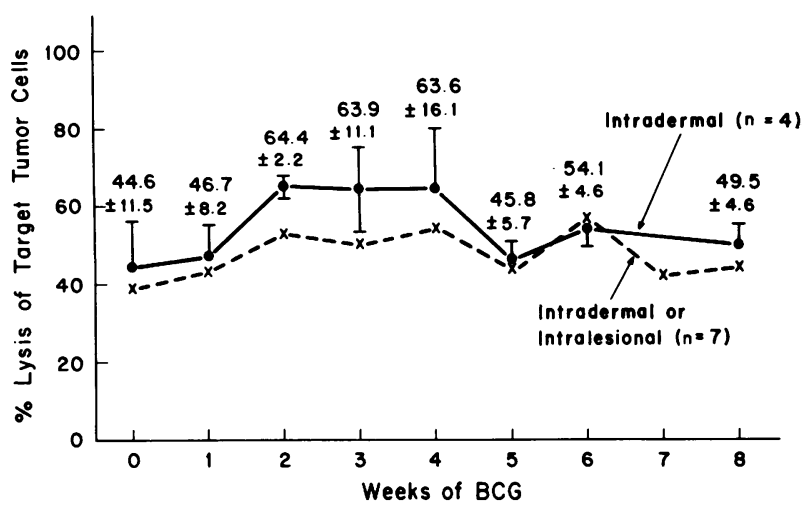

FIGURE 3 Effect of intradermal or intralesional BCG on lymphocyte-mediated lysis of melanoma cells in seven patients. Mean $\pm \mathrm{SE}$ given for each point.

ranging from 0.2 to $3 \times 10^{7}$ viable units weekly for 4 wk-3 mo, then biweekly for 3 more mo or until relapse. There was a transient increase in CMI in four of five patients treated with intradermal BCG within 2 mo of initiation of therapy (Fig. 3 and Appendix II). Despite continuation of BCG, CMI returned essentially to pretreatment levels in all but two patients. It was possible to increase CMI again by increasing the dose of intradermal BCG, but the severity of local inflammatory reactions made continuation at these high levels infeasible. All patients but L. R. and B. $H$. have relapsed with melanoma.

Intralesional BCG was effective in causing the rejection of dermal nodules in two of three patients (E. H. and M. G.). CMI reached a peak in $5 \mathrm{wk}$ in two of the three, but declined rapidly in both. The third patient had no increase despite a good clinical response.

Of some concern was the appearance of $\mathrm{BF}$ in several patients during immunoprophylaxis with BCG. Three patients with no evidence of disease whose serum did not block CMI before therapy developed BF within 12 wk of the initiation of therapy. One of these, A. J., had a significant rise in CMI but was later found to have $\mathrm{BF}$ coincident with the clinical complaint of ataxia. Paraspinal metastasis was discovered and resected, but widespread dissemination occurred shortly thereafter. L. R., a 44-yr-old man, developed BF 12 wk after starting BCG, which was stopped after eight injections in July 1972. BF was again present 2 mo later, but was absent 18 and 27 mo later. As of January 1977 there is no evidence of recurrent disease. E. W. developed BF when her nasopharyngeal melanoma recurred and disseminated. Three patients had consistent helper activity of serum, i.e., their serum elevated CMI $20 \%$ on three or more occasions. However, two of them developed widely metastatic disease within $4 \mathrm{mo}$, making the in vivo significance of this finding uncertain.

Case reports. (a) M. L. P., a 28-yr-old woman, deserves specific mention. She was a patient with Hodgkin's Disease, Stage IV, treated with single agents for $2 \mathrm{yr}$ before developing a malignant melanoma on her back in 1971. The melanoma was resected and did not recur for the remainder of her life $(1 \mathrm{yr})$. Despite late stage Hodgkin's Disease she had demonstrable cellular immunity to melanoma 6 mo after resection, and could be sensitized to dinitrochlorobenzene. Treatment with CCNU (130 mg/m²) for her Hodgkin's Disease suppressed what was in essence a stable circulating level of CMI to melanoma antigens. She exhibited the same pattern of transiently decreased CMI and rapid recovery that was characteristic of patients with metastatic melanoma. Incidentally, subsequent therapy with weekly vincristine (1-2 mg) and daily prednisone (20-60 $\mathrm{mg}$ ) failed to alter CMI (Fig. 4).

(b) J. P., a 55-yr-old man, was given BCG intradermally despite a residual $5 \mathrm{~mm}$ intradermal nodule at the periphery of the grafted site of primary resection. His course underscores many of the points we have described above, and so is presented graphically in Fig. 5. Within 2 wk after surgical removal of a large subcutaneous tumor mass, BF was undetectable in the serum. No medical therapy was given during this period. BCG intradermally and intralesionally

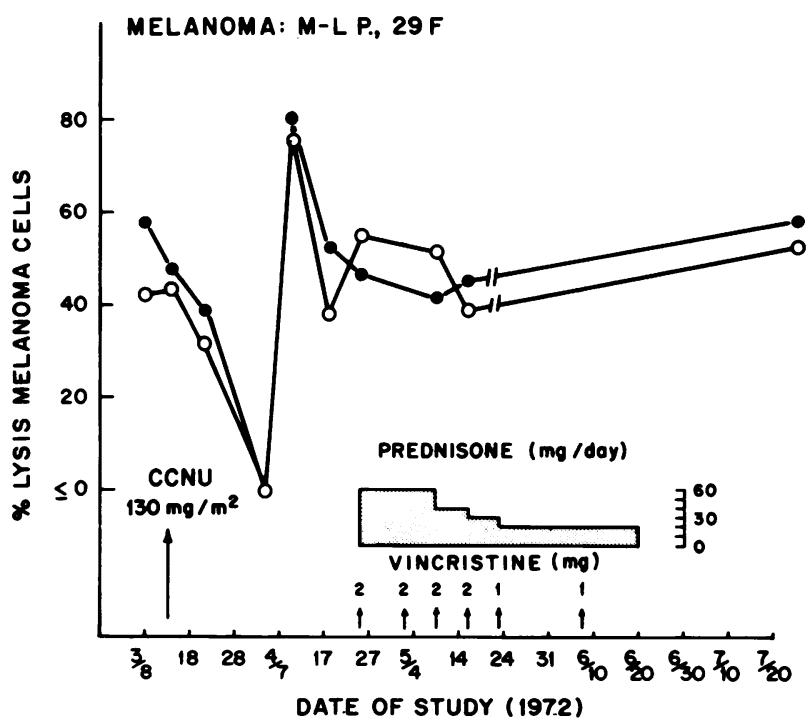

FIGURE 4 Effect of CCNU on lymphocyte-mediated lysis of melanoma cells in a patient with Hodgkin's disease and a primary melanoma removed 6 mo before the study. Closed circles: CMI in absence of patient's serum; open circles: CMI in the presence of patient's serum. 


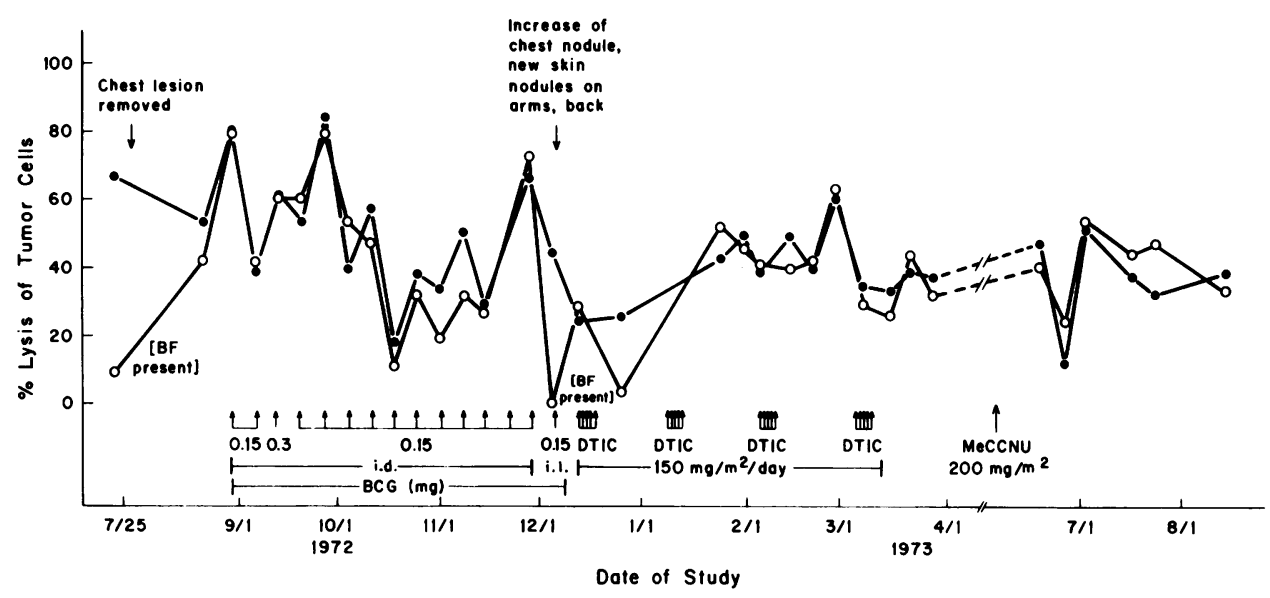

FIGURE 5 Effects of surgery, immunotherapy, and chemotherapy on lymphocyte-mediated lysis of melanoma cells, and on blocking factor in patient J. P. Note that neither BCG nor DTIC significantly affected CMI. Blocking was present initially and at relapse, and was abolished by removal of tumor by surgery or successful chemotherapy. Therapy with methyl CCNU caused transient diminution of CMI. Symbols as in Fig. 4. i.d., intradermal; i.l., intralesional.

on one occasion failed to alter CMI over the course of months. When evidence of disseminated disease was found, coincident with the appearance of blocking activity in the serum, he was treated with DTIC and later with methyl-CCNU. Each of these agents caused significant regression of subcutaneous lesions until clinical resistance developed. BF was present during one relapse and was abolished by therapy with DTIC, reappearing during a subsequent relapse. Note the lack of immunosuppression of CMI due to DTIC and the transient decrease seen with methylCCNU.

\section{DISCUSSION}

The cellular immune response to tumors may be of considerable importance in determining the outcome of tumoricidal chemotherapy. Thus, the lack of immunosuppression of CMI by DTIC and the transient decline produced by nitrosoureas are encouraging. If an agent is immunosuppressive but not tumoricidal, the growth of even highly antigenic tumors can be facilitated (18). Towards the other extreme, if an agent is highly tumoricidal it can be effective even if it is also immunosuppressive (19). Most of the agents used in cancer chemotherapy are immunosuppressive when tested against exogenous antigens (1), but it would be an oversimplification to refer to cancer chemotherapy as immunosuppressive therapy. Several agents do not suppress immunity to any significant degree, including mithramycin, ${ }^{3}$ bleomycin (20-22),

${ }^{3}$ Mitchell, M. S. Unpublished data.
DTIC (7), and dimethylmyleran (23). Other agents, particularly antimetabolites, are often suppressive only during the period of administration with rapid recovery of immunological responsiveness afterwards $(5,24)$. Furthermore, established immunological reactivity, such as pre-existent delayed hypersensitivity (CMI) to microbial antigens, is usually resistant to immunosuppression by chemicals $(4,5)$.

DTIC was only minimally immunosuppressive at dosage schedules similar to these in two previous studies, one of which involved several of the patients reported here and tested with a battery of exogenous antigens. In that study established delayed sensitivity was unaffected in eight patients and the anamnestic (secondary) antibody response was normal in 7 of 12 patients (7). The other report dealt with reactivity to melanoma cells, in which 10 of 12 patients treated with DTIC showed no significant suppression of responsiveness (25). Nitrosoureas have not previously been studied as thoroughly as DTIC, but the same relative lack of suppression of tumorspecific CMI by these agents, which closely resemble alkylating agents, has been observed in studies with phenylalanine mustard (melphalan) and cyclophosphamide (Cytoxan) in patients with ovarian carcinoma (26). This suggests that CMI to tumor cells may be seen as a form of established delayed sensitivity, and shares the resistance of this form of delayed sensitivity to immunosuppression. The parallel results with other agents and another tumor indicates that our results with melanoma were not due simply to a fortunate choice of agents and disease. 
Chemotherapy that was successful in causing regression of disease actually had a beneficial effect upon tumor-specific immunity, at least as measured in vitro, leading to a decrease in $\mathrm{BF}$. It is likely that the disappearance of $\mathrm{BF}$ was the consequence of decreased tumor size and not a suppression of blocking antibody. BF may be an antigen-antibody complex (27, 28); antigen alone can also block CMI (29), but antibody alone cannot (29) except under very restricted conditions. Since DTIC is usually not immunosuppressive towards antibody synthesis (7), it is most probable that the decrease in BF found in patients responding to DTIC was the result of a decreased input of tumor antigen from the decreased tumor burden. The decrease in $\mathrm{BF}$ in $\mathrm{J}$. $\mathrm{P}$. as a consequence of surgical removal of a tumor mass further strengthens this assertion. Whether the decrease in $\mathrm{BF}$ then facilitated the rejection of tumor cells by sensitized lymphocytes and macrophages in vivo is an intriguing but unresolved issue.

The appearance of serum BF during therapy with BCG was disturbing, but could not be firmly correlated with in vivo enhancement of tumor growth. Patients A. J. and J. P. had melanoma that became metastatic coincident with the appearance of $\mathrm{BF}$, but the increased tumor could have caused $\mathrm{BF}$ rather than vice versa. Patient L. R. had BF without apparent metastatic disease on several occasions, finally losing BF with continuing good health. An increase in the antibody component of BF by BCG is a distinct possibility in this patient, but in any event BF had no immediate adverse effect. BCG can enhance the growth of established tumors in mice (30-32), but small inocula of tumor cells have usually regressed or shown no change (31). Levy et al. (33) reported the dissemination of a melanoma in man after intralesional BCG, with the concomitant appearance of BF, but a causal relationship was impossible to prove. Needless to say, however, the appearance of BF during monitoring of a patient receiving an immunological adjuvant should probably spur an investigation for metastatic disease as a precautionary measure.

Despite administering BCG to the limits of local tolerance by the intradermal or intralesional route, we could not demonstrate a long-lived influence on CMI. There was a transient rise in CMI in seven of nine patients, but within 2 mo CMI returned to pretreatment levels. It is possible that the route of administration caused the poor response, but we have also found inconsistent stimulation of CMI by BCG given by the multiprong technic. ${ }^{4}$ These results were

${ }^{4}$ Mitchell, M. S., M. B. Mokyr, and J. M. Davis. Unpublished data. obtained with [125I]5-iodo-2'-deoxyuridine-labeled melanoma cells and an established line of melanoma cells, making exact comparison with the present results somewhat complicated. Nevertheless, the trend of the results with multiprong vaccination with BCG was the same. It is entirely possible that the dose and strain of BCG were responsible for poor immunostimulation, but this point must await direct comparisons. While the ultimate judgment of the utility of BCG will be based on the therapeutic evidence from randomized controlled trials and not from our limited data, we have not yet adduced supportive immunological evidence for its efficacy.

It should be emphasized that we were concerned in these studies almost exclusively with the effects of therapy on immunity to tumor associated antigens and not the clinical response, yet we hoped that the assay chosen might reflect in vivo antitumor immunity. Several investigators $(9,11)$ have found general correlations between the clinical course of patients with melanoma and levels of CMI and BF, measured in the peripheral blood, although individual patients have shown some discrepancies. A far stronger correlation has been found in animals with various tumors (3). While several of our patients manifested changes in measurable immunity concomitant with a change in clinical status, such as a decrease in CMI or development of $\mathrm{BF}$ when metastasis occurred or metastatic disease progressed, several others did not. BF was not invariably found even in patients with disseminated disease with our assay, which differs in several major respects (such as total volume of the incubation mixture and the use of phase-contrast microscopy) from the original microcytoxicity assay. Heppner et al. (11), with microcytotoxicity, also found $\mathrm{BF}$ absent at times in several such patients. In their study as in ours however, only those patients with disseminated disease had BF. It is impossible at this time to assert that immunity of peripheral blood lymphocytes against tumor cells indicates the patient's clinical status or prognosis any better than nonspecific tests of immunocompetence. Yet it seems logical and worthwhile to try to measure immunity to tumor-associated antigens, preferably with a variety of assays for CMI and antibodies, if one is specifically concerned with the patient's immunity to his tumor. Only comparative studies of nonspecific and tumor-specific assays can answer which is more useful. As a start, long-term serial testing of various groups of cancer patients through different stages of their disease and different forms of therapy should help to clarify whether lymphocyte-mediated cytotoxicity or any test of tumor-specific immunity is an accurate reflection of the in vivo circumstances. 


\begin{tabular}{|c|c|c|c|c|c|c|c|c|c|c|c|c|}
\hline \multirow[b]{3}{*}{ Patient } & \multirow[b]{3}{*}{ Age } & \multirow[b]{3}{*}{ Sex } & \multirow[b]{3}{*}{$\begin{array}{l}\text { Initial sites } \\
\text { of disease }\end{array}$} & \multirow{2}{*}{\multicolumn{2}{|c|}{ Treatment }} & \multirow[b]{3}{*}{ Response* } & \multirow[b]{3}{*}{$\begin{array}{c}\text { Target } \\
\text { tumor cells }\end{array}$} & \multicolumn{2}{|c|}{ CMI, \% lysis } & \multicolumn{2}{|c|}{$\begin{array}{l}\text { Blocking } \\
\text { factor }\end{array}$} & \multirow{3}{*}{$\begin{array}{l}\text { Total } \\
\text { period of } \\
\text { follow-ul) } \\
\text { with } \\
\text { immuno- } \\
\text { logical } \\
\text { tests }\end{array}$} \\
\hline & & & & & & & & \multirow{2}{*}{$\begin{array}{l}\text { Be- } \\
\text { fore } \\
\text { ther- } \\
\text { apy }\end{array}$} & \multirow{2}{*}{$\begin{array}{l}\text { Nadir } \\
\text { after a } \\
\text { course } \\
\text { of ther- } \\
\text { apy }\end{array}$} & \multirow{2}{*}{$\begin{array}{l}\text { Be- } \\
\text { fore } \\
\text { ther- } \\
\text { apy }\end{array}$} & \multirow{2}{*}{$\begin{array}{l}\text { After } \\
\text { ther- } \\
\text { apy }\end{array}$} & \\
\hline & & & & Agent Schedule & $\begin{array}{l}\text { No. of } \\
\text { courses }\end{array}$ & & & & & & & \\
\hline & & & & & & & & & & & & mo \\
\hline \multirow[t]{2}{*}{ J. McH. } & 40 & $\mathrm{~F}$ & $\begin{array}{l}\text { Subcutaneous, } \\
\text { nodes }\end{array}$ & $\begin{array}{l}\text { DTIC } 250 \mathrm{mg} / \mathrm{m}^{2} / \mathrm{day} \\
\times 5 \mathrm{q} \$ 3 \mathrm{wk}\end{array}$ & 3 & Remission & Autologous & 67 & 0 & + & - & $3-1 / 2$ \\
\hline & & & & $\begin{array}{l}\mathrm{CCNU} 130 \mathrm{mg} / \mathrm{m}^{2} \\
+\mathrm{VCR} \$ 1.4 \mathrm{mg} / \mathrm{m}^{2}\end{array}$ & 2 & N. R. & Autologous & 65 & 0 & - & - & $3-1 / 2$ \\
\hline A. $S$. & 29 & $\mathbf{M}$ & $\begin{array}{l}\text { Subcutaneous, } \\
\text { lung }\end{array}$ & $\begin{array}{l}\text { DTIC } 150 \mathrm{mg} / \mathrm{m}^{2} / \text { day } \\
\times 5 \mathrm{q} 4 \mathrm{wk}\end{array}$ & 3 & N. R. & $\begin{array}{l}\text { Allogenic } \\
\quad \text { (J. McH) }\end{array}$ & 90 & 43 & - & - & 7 \\
\hline \multirow[t]{2}{*}{ J. P. } & 55 & $\mathbf{M}$ & Subcutaneous & $\begin{array}{l}\text { DTIC } 150 \mathrm{mg} / \mathrm{m}^{2} / \text { day } \\
\times 5 \mathrm{q} 3 \mathrm{wk}\end{array}$ & 4 & Remission & $\begin{array}{l}\text { Autologous } \\
\text { and allogenic } \\
\text { (J. McH) }\end{array}$ & 39 & 33 & + & - & 15 \\
\hline & & & & $\mathrm{Me}^{\|} \mathrm{CCNU} 200 \mathrm{mg} / \mathrm{m}^{2}$ & 1 & Remission & $\begin{array}{l}\text { Autologous } \\
\text { and allogenic } \\
\text { (J. McH) }\end{array}$ & & & & & \\
\hline \multirow[t]{2}{*}{ P. D. } & 50 & $\mathbf{F}$ & $\begin{array}{l}\text { Subcutaneous, } \\
\text { brain }\end{array}$ & $\begin{array}{l}\text { DTIC } 150 \mathrm{mg} / \mathrm{m}^{2} / \text { day } \\
\times 5 \mathrm{q} 3 \mathrm{wk}\end{array}$ & 4 & N. R. & $\begin{array}{l}\text { Allogenic } \\
\text { (E. H.) }\end{array}$ & 32 & 36 & - & - & 5 \\
\hline & & & & $\begin{array}{l}\text { VCR } 1.4 \mathrm{mg} / \mathrm{m}^{2}+\mathrm{CCNU} \\
130 \mathrm{mg} / \mathrm{m}^{2} \mathrm{q} 6 \mathrm{wk}\end{array}$ & 2 & N. R. & $\begin{array}{c}\text { Allogenic } \\
\text { (E. H.) }\end{array}$ & 35 & 5 & - & - & \\
\hline \multirow[t]{2}{*}{ R. H. } & 41 & $\mathbf{M}$ & Lung & $\mathrm{Me} \mathrm{CCNU} 200 \mathrm{mg} / \mathrm{m}^{2}$ & 1 & N. $\mathbf{R}$. & $\begin{array}{l}\text { Allogenic } \\
\text { (E. H.) }\end{array}$ & 45 & 16 & - & - & 4 \\
\hline & & & & $\begin{array}{l}\text { DTIC } 200 \mathrm{mg} / \mathrm{m}^{2} / \mathrm{day} \\
\times 5 \mathrm{q} 3 \mathrm{wk}\end{array}$ & 3 & N. $\mathbf{R}$. & $\begin{array}{l}\text { Allogenic } \\
\text { (E. H.) }\end{array}$ & 46 & 28 & & & \\
\hline \multirow[t]{2}{*}{ S. C. } & 48 & F & $\begin{array}{l}\text { Subcutaneous, } \\
\text { nodes }\end{array}$ & $\begin{array}{l}\text { DTIC } 200 \mathrm{mg} / \mathrm{m}^{2} / \text { day } \\
\times 5 \mathrm{q} 3 \mathrm{wk}\end{array}$ & 4 & Remission & $\begin{array}{l}\text { Allogenic } \\
\text { (E. H.) }\end{array}$ & 35 & 18 & - & - & 5 \\
\hline & & & & $\mathrm{Me} \mathrm{CCNU} 200 \mathrm{mg} / \mathrm{m}^{2}$ & 1 & N. R. & $\begin{array}{c}\text { Allogenic } \\
\text { (E. H.) }\end{array}$ & 32 & 3 & & & \\
\hline \multirow[t]{2}{*}{ K. P. } & 33 & F & $\begin{array}{l}\text { Brain, lung, } \\
\text { subcuta- } \\
\text { neous }\end{array}$ & $\begin{array}{l}\text { DTIC } 200 \mathrm{mg} / \mathrm{m}^{2} / \text { day } \\
\times 5 \mathrm{q} 3 \mathrm{wk}\end{array}$ & 3 & N. R. & $\begin{array}{l}\text { Allogenic } \\
\text { (E. H.) }\end{array}$ & 28 & 35 & - & - & 4 \\
\hline & & & & $\mathrm{Me} \mathrm{CCNU} 200 \mathrm{mg} / \mathrm{m}^{2}$ & 1 & N. R. & $\begin{array}{l}\text { Allogenic } \\
\text { (E. H.) }\end{array}$ & 30 & -4 & - & - & \\
\hline F. M. & 25 & $\mathbf{M}$ & $\begin{array}{c}\text { Gastrointes- } \\
\text { tinal tract }\end{array}$ & $\begin{array}{l}\text { DTIC } 150 \mathrm{mg} / \mathrm{m}^{2} / \mathrm{day} \\
\times 5 \mathrm{q} 3 \mathrm{wk}\end{array}$ & 2 & N. R. & $\begin{array}{l}\text { Allogenic } \\
\text { (E. H.) }\end{array}$ & 31 & 27 & - & - & 4 \\
\hline A. $\mathrm{H}$. & 45 & $\mathbf{M}$ & $\begin{array}{l}\text { Gastrointes- } \\
\text { tinal, nodes }\end{array}$ & $\begin{array}{l}\text { DTIC } 250 \mathrm{mg} / \mathrm{m}^{2} / \text { day } \\
\times 5 \mathrm{q} 3 \mathrm{wk}\end{array}$ & 3 & N. R. & $\begin{array}{l}\text { Allogenic } \\
\text { (E. H.) }\end{array}$ & 27 & 44 & - & - & 2 \\
\hline E. $S$. & 47 & $\mathbf{F}$ & $\begin{array}{l}\text { Subcutaneous, } \\
\text { nodes, liver }\end{array}$ & $\begin{array}{l}\text { DTIC } 100 \mathrm{mg} / \mathrm{m}^{2} / \mathrm{day} \times 5 \\
+\mathrm{Me} \text { CCNU } 100 \mathrm{mg} / \mathrm{m}^{2}\end{array}$ & $\begin{array}{l}(4) \\
(2)\end{array}$ & N. R. & $\begin{array}{l}\text { Allogenic } \\
\text { (E. H.) }\end{array}$ & 75 & 24 & - & - & $3-1 / 2$ \\
\hline W. C. & 59 & M & $\begin{array}{l}\text { Retroperi- } \\
\text { toneal }\end{array}$ & $\begin{array}{l}\text { DTIC } 100 \mathrm{mg} / \mathrm{m}^{2} / \mathrm{day} \\
\times 5+\mathrm{Me} \mathrm{CCNU} 100 \mathrm{mg} / \\
\mathrm{m}^{2}\end{array}$ & $\begin{array}{l}(2) \\
(1)\end{array}$ & N. R. & $\begin{array}{l}\text { Allogenic } \\
\qquad(\mathrm{J} . \mathrm{McH})\end{array}$ & 56 & 10 & - & - & 2 \\
\hline R. P. & 43 & F & $\begin{array}{l}\text { Subcutaneous, } \\
\text { intradermal }\end{array}$ & $\begin{array}{l}\mathrm{Me} \mathrm{CCNU} 200 \mathrm{mg} / \mathrm{m}^{2} \\
\mathrm{q} 6 \mathrm{wk}\end{array}$ & 3 & $\begin{array}{l}\text { Partial re- } \\
\text { mission }\end{array}$ & $\begin{array}{l}\text { Autologous and } \\
\text { allogenic } \\
\text { (J. McH) }\end{array}$ & 54 & 36 & + & - & 5 \\
\hline M. L. P. & 28 & $\mathrm{~F}$ & $\begin{array}{l}\mathrm{S} / \mathrm{P} \text { removal of } \\
\text { primary } \\
\text { (back) lesion }\end{array}$ & $\mathrm{CCNU} 130 \mathrm{mg} / \mathrm{m}^{2}$ & 1 & N. E. & $\begin{array}{l}\text { Allogenic } \\
\quad(\mathrm{J} . \mathrm{McH})\end{array}$ & 58 & 0 & - & - & $4-1 / 2$ \\
\hline J. J. & 55 & F & $\begin{array}{l}\text { Lung, brain, } \\
\text { bone }\end{array}$ & $\mathrm{Me} \mathrm{CCNU} 200 \mathrm{mg} / \mathrm{m}^{2}$ & 1 & N. $\mathbf{R}$. & $\begin{array}{c}\text { Allogenic } \\
\text { (E. H.) }\end{array}$ & 36 & 38 & - & - & $1-1 / 2$ \\
\hline
\end{tabular}

* N. R., No response; N. E., Not evaluable. $\ddagger$ q, every.

$\$$ VCR, vincristine.

"Me CCNU, methyl-CCNU. 


\begin{tabular}{|c|c|c|c|c|c|c|c|c|c|c|c|c|c|}
\hline \multirow[b]{2}{*}{ Patient } & \multirow[b]{2}{*}{ Age } & \multirow[b]{2}{*}{ Sex } & \multirow[b]{2}{*}{ Initial status* } & \multirow[b]{2}{*}{ Dose (viable units) } & \multirow[b]{2}{*}{ Routef } & \multirow[b]{2}{*}{ Target tumor cells } & \multicolumn{2}{|c|}{ CMI } & \multicolumn{2}{|c|}{$\begin{array}{c}\text { "Helper" } \\
\text { factor }\end{array}$} & \multicolumn{2}{|c|}{$\begin{array}{l}\text { Blocking } \\
\text { factor }\end{array}$} & \multirow{2}{*}{$\begin{array}{l}\text { Period of } \\
\text { follow-up } \\
\text { with } \\
\text { immuno- } \\
\text { logical } \\
\text { testing }\end{array}$} \\
\hline & & & & & & & $\begin{array}{l}\text { Be- } \\
\text { fore } \\
\text { ther- } \\
\text { apy }\end{array}$ & $\begin{array}{c}\text { Peak } \\
\text { during } \\
\text { therapy }\end{array}$ & $\begin{array}{l}\text { Be- } \\
\text { fore } \\
\text { Rx }\end{array}$ & $\begin{array}{l}\text { Dur- } \\
\text { ing } \\
\mathbf{R x}\end{array}$ & $\begin{array}{l}\text { Be- } \\
\text { fore } \\
\text { ther- } \\
\text { apy }\end{array}$ & $\begin{array}{l}\text { After } \\
\text { ther- } \\
\text { apy }\end{array}$ & \\
\hline J.P. & 55 & $\mathbf{M}$ & $\begin{array}{l}1 \text { Intradermal and } 1 \\
\text { subcutaneous } \\
\text { lesion }\end{array}$ & $0.15 \mathrm{mg}\left(2 \times 10^{6}\right)$ & $\begin{array}{l}\text { i. d. }+ \text { i. } 1 . \\
(\times 1)\end{array}$ & Allogenic (J. McH) & 53 & 80 & - & - & - & + & $15 \mathrm{mo}$ \\
\hline A. J. & 60 & $\mathbf{F}$ & N. E. D. & $0.3 \mathrm{mg}\left(4 \times 10^{6}\right)$ & i. $\mathrm{d}$. & Allogenic (J. McH) & 27 & 97 & - & - & - & + & $2 \mathrm{mo}$ \\
\hline L. R. & 44 & $\mathbf{M}$ & N. E. D. & $0.3 \mathrm{mg}\left(4 \times 10^{6}\right)$ & i. d. & Allogenic (J. McH) & 43 & 74 & - & - & - & $+\S$ & $3 \mathrm{yr}+$ \\
\hline B. H. & 37 & $\mathrm{~F}$ & $\begin{array}{l}\text { N.E. D. (1 recurrence } \\
\text { after resection of } \\
\text { primary) }\end{array}$ & $1.2-5 \times 10^{6}$ & $\begin{array}{l}\text { i. d. }+ \\
\text { Heaf }\end{array}$ & Allogenic (E. H.) & 34 & 66 & - & + & - & - & $2 \mathrm{yr}+$ \\
\hline B. $\mathbf{W}$. & 50 & $\mathbf{M}$ & N. E. D. & $\begin{array}{l}1 \times 10^{6} \text { i. d.; } 0.1-5 \\
\times 10^{8}(\text { Heaf })\end{array}$ & i. d. + & Allogenic (E. H.) & 43 & 61 & - & + & - & - & $6 \mathrm{mo}$ \\
\hline E. H. & 50 & $\mathrm{~F}$ & $\begin{array}{l}\text { Intradermal } \\
\text { metastases }\end{array}$ & $\begin{array}{l}0.3-0.9 \mathrm{mg} \\
\quad\left(1-2 \times 10^{7}\right)\end{array}$ & i. 1. & Autologous & 63 & 63 & - & + & + & - & $4 \mathrm{mo}$ \\
\hline M. G. & 43 & $\mathbf{F}$ & Intradermal & $0.6 \mathrm{mg}$ & i. 1. & Allogenic (E. H.) & 34 & $56^{\prime \prime}$ & - & - & - & - & $7 w k$ \\
\hline N. B. & 31 & $\mathrm{~F}$ & $\begin{array}{l}\text { Intradermal } \\
\text { metastases }\end{array}$ & $0.3-2 \times 10^{7}$ total & i. 1. & Allogenic (E. H.) & 22 & 66 & - & - & - & - & $14 \mathrm{mo}$ \\
\hline E. W. & 68 & $\mathrm{~F}$ & $\begin{array}{l}\text { Residual tumor in } \\
\text { nasopharynx after } \\
\text { cryosurgery }\end{array}$ & $0.2-1 \times 10^{7}$ & Heaf & Allogenic (E. H.) & 48 & 559 & - & - & - & + & $4 \mathrm{mo}$ \\
\hline
\end{tabular}

* N. E. D., no evidence of disease.

f i. d., intradermal, i. l., intralesional; Heaf, multiprong vaccination via Heaf gun. $\$$ Blocking activity disappeared after 6 mo.

"Developed hepatic granulomas.

Initial decline to $10 \%$ lysis at $4 \mathrm{wk}$.

\section{ACKNOWLEDGMENTS}

It is a pleasure to acknowledge the help of Dr. Michael B. Mosher and Dr. Howard Bruckner in obtaining specimens and caring for the patients. Sue Hubbard, R.N., Bonny Johnson, R.N., Tish Knobf, R.N., and Patricia Kono, R.N., also provided excellent assistance without which these serial studies would have been impossible.

This paper was supported by U. S. Public Health Service grant no. CA 13105 and American Cancer Society grant no. IM 50B.

\section{REFERENCES}

1. Makinodan, T., G. W. Santos, and R. P. Quinn. 1970. Immunosuppressive drugs. Pharmacol. Rev. 22: 189247.

2. Prehn, R. T., and J. M. Main. 1957. Immunity to methylcholanthrene-induced sarcomas. J. Natl. Cancer Inst. 18: 769-778.

3. Hellström, K. E., and I. Hellström. 1974. Lymphocytemediated cytotoxicity and blocking serum activity to tumor antigens. Adv. Immunol. 18: 209-277.

4. Santos, G. W., A. H. Owens, Jr., and L. L. Sensenbrenner. 1964. Effects of selected cytotoxic agents on antibody production in man; a preliminary report. Ann. N. Y. Acad. Sci. 114: 404-423.

5. Mitchell, M. S., M. E. Wade, R. C. DeConti, J. R. Bertino, and P. Calabresi. 1969. Immunosuppressive effects of cytosine arabinoside and methotrexate in man. Ann. Intern. Med. 70: 535-547.

6. Mitchell, M. S., and R. C. DeConti. 1970. Immunosuppression by 5-fluorouracil. Cancer. 26: 884-889.

7. Bruckner, H. W., M. B. Mokyr, and M. S. Mitchell 1974. Effect of imidazole-4-carboxamide, 5-(3,3-dimethyl1-triazeno) on immunity in patients with malignant melanoma. Cancer Res. 34: 181-183.

8. Hellström, I., K. E. Hellström, H. O. Sjögren, and G. A. Warner. 1971. Demonstration of cell-mediated immunity to human neoplasms of various histological types. Int. J. Cancer 7: 1-16.

9. Hellström, I., G. A. Warner, K. E. Hellström, and H. O. Sjögren. Sequential studies on cell-mediated tumor immunity and blocking serum activity in ten patients with malignant melanoma. Int. J. Cancer. 11: 280-292.

10. Hellström, I., and K. E. Hellström. 1973. Some recent studies on cellular immunity to human melanomas. Fed. Proc. 32: 156-159.

11. Heppner, G. H., L. Stolbach, M. Byrne, F. J. Cummings, E. McDonough, and P. Calabresi. 1973. Cell-mediated and serum blocking reactivity to tumor antigens in patients with malignant melanoma. Int. J. Cancer. 11: 245-260.

12. De Vries, J. E., S. Cornain, and P. Rümke. 1974. Cytotoxicity of non- $T$ versus $T$-lymphocytes from melanoma patients and healthy donors on short- and long-term cultured melanoma cells. Int. J. Cancer. 14: 427-434.

13. Mavligit, G., J. N. Gutterman, C. McBride, and E. M. 
Hersh. 1974. Tumor-directed immune reactivity and immunotherapy in malignant melanoma. Current status. Prog. Exp. Tumor Res. 19: Basel-Karger, 222-252.

14. Morton, D. L., F. R. Eilber, R. A. Malmgren, and W. C. Wood. 1970. Immunological factors which influence response to immunotherapy in malignant melanoma. Surgery (St. Louis). 68: 158-164.

15. Hellström, I., and K. E. Hellström. 1971. Colony inhibition and cytotoxicity assays. In In Vitro Methods in Cell-Mediated Immunity. B. R. Bloom and P. R. Glade, editors. Academic Press, Inc., New York. 409-414.

16. Takasugi, M., and E. Klein. 1970. A microassay for cell-mediated immunity. Transplantation (Baltimore). 9: 219-227.

17. Perper, R. J., T. W. Zee, and M. M. Mickelson. 1968. Purification of lymphocytes and platelets by gradient centrifugation. J. Lab. Clin. Med. 72: 842-848.

18. Humphreys, S. R., M. A. Chirigos, K. L. Milstead, N. Mantel, and A. Goldin. 1961. Studies on the suppression of the homograft response with folic and antagonists. J. Natl. Cancer Inst. 27: 259-276.

19. Mihich, E. 1969. Combined effects of chemotherapy and immunity against leukemia L1210 sublines in DBA/2 mice. Cancer Res. 29: 848-854.

20. Ohno, R., H. Nisiwaki, K. Kawashima, T. Uetani, M. Hirano, M. Miura, and K. Tamada. 1971. Lack of immunosuppressive effect of bleomycin on the primary response of mice to sheep red blood cells. Gann. 62: 267-274.

21. Dlugi, A. M., K. M. Robie, and M. S. Mitchell. 1974. Failure of bleomycin to affect humoral or cell-mediated immunity in the mouse. Cancer Res. 34: 2504-2507.

22. Lehane, D. E., E. Hurd, and M. Lane. 1975. The effects of bleomycin on immunocompetence in man. Cancer Res. 35: 2724-2728.

23. Kolb, H. J., R. Storb, P. L. Weiden, H. D. Ochs, H. Kolb, T. C. Graham, G. L. Floersheim, and E. D. Thomas. 1974. Immunologic, toxicologic and marrow transplantation studies in dogs given dimethyl myleran. Biomedicine (Paris). 20: 341-351.

24. Hersh, E. M., V. G. Wong, and E. J. Freireich. 1966.
Inhibition of the local inflammatory response by antimetabolites. Blood. 27: 38-48.

25. Cummings, F. J., G. H. Heppner, M. Byrne, L. Stolbach, and P. Calabresi. 1973. Effects of chemotherapy on cell-mediated immunity and serum blocking factors in malignant melanoma. Proc. Am. Assoc. Cancer Res. 14: 122. (Abstr.)

26. Mitchell, M. S., and E. I. Kohorn. 1976. Cell-mediated immunity and blocking factor in ovarian carcinoma. Obstet. Gynecol. 48: 590-597.

27. Sjögren, H. O., I. Hellström, S. C. Bansal, and K. E Hellström. 1971. Suggestive evidence that the "blocking antibodies" of tumor-bearing individuals may be antigen-antibody complexes. Proc. Natl. Acad. Sci. U.S.A. 68: $1372-1375$.

28. Baldwin, R. W., M. R. Price, and R. A. Robins. 1972. Blocking of lymphocyte-mediated cytotoxicity for rat hepatoma cells by tumour-specific antigen-antibody complexes. Nat. New Biol. 238: 185-187.

29. Baldwin, R. W., M. R. Price, and R. A. Robins. 1973. Inhibition of hepatoma-immune lymph-node cell cytotoxicity by tumour-bearer serum, and solubilized hepatoma antigen. Int. J. Cancer. 11: 527-535.

30. Piessens, W. F., R. Heimann, N. Legros, and J.-C. Heuson. 1971. Effect of Bacillus Calmette-Guérin on mammary tumour formation and cellular immunity in dimethylbenz(a)anthracene-treated rats. Cancer Res. 31: $1061-1065$.

31. Mathé, G., M. Kamel, M. Dezfulian, O. Halle-Pannenko, and C. Bourut. 1973. An experimental screening for "systemic adjuvants of immunity" applicable in cancer immunotherapy. Cancer Res. 33: 1987-1997.

32. Lavrin, D. H., S. A. Rosenberg, R. J. Connor, and W. D. Terry. 1973. Immunoprophylaxis of methylcholanthreneinduced tumors in mice with Bacillus CalmetteGuérin and methanol-extracted residue. Cancer Res. 33: 472-477.

33. Levy, N. L., M. S. Mahaley, Jr., and E. D. Day. 1972. Serum-mediated blocking of cell-mediated anti-tumor immunity in a melanoma patient: association with BCG immunotherapy and clinical deterioration. Int. J. Cancer. 10: 244-248. 